\title{
Peningkatan Pemahaman Guru-Guru SMK melalui Pelatihan Akuntansi Pemerintah Guna Menyiapkan SDM Instansi Pemerintah
}

Ratna Anggraini ${ }^{1,}$ Nuramalia Hasanah ${ }^{2,}$ Ahmad Fauzi ${ }^{3}$ Tri Hesti Utaminingtyas ${ }^{4}$.

${ }^{1}$ Universitas Negeri Jakarta

${ }^{2}$ Universitas Negeri Jakarta

${ }^{3}$ Universitas Negeri Jakarta

${ }^{4}$ Universitas Negeri Jakarta

\section{ARTICLE INFO}

\section{Article history:}

Received: $20^{\text {th }}$ October 2018

Accepted: $24^{\text {th }}$ November 2018

Published: $1^{\text {st }}$ December 2018

Keywords:

Vocational Teachers, Government Accounting, Human Resources.

\section{ABSTRACT}

The development of the implementation of financial accountability in government institutions, demands an increase in the number of human resources as executors of activities. Vocational secondary schools are government institutions that produce human resources that are ready to use are required to help fulfill these resources. Correspondingly, the government established a government accounting curriculum in vocational high schools in 2018. However, the constraints faced by vocational teachers in the accounting field, many still do not understand policy changes in government accounting, even though they are required to be able to teach government accounting subjects in the class.

Responding to this, Jakarta State University as an educational institution is obliged to carry out community service to conduct training activities for vocational teachers in East Jakarta in an effort to increase the capacity to prepare government institutions for the government.

How to cite: Anggraini, R., Hasanah, N., Fauzi, A., \& Utaminingtyas, T. (2018, November 26). Peningkatan Pemahaman Guru - Guru SMK Melalui Pelatihan Akuntansi Pemerintah Guna Menyiapkan SDM Instansi Pemerintah. Jurnal Pemberdayaan Masyarakat Madani (JPMM), 2(2), 338-354. https://doi.org/https://doi.org/10.21009/JPMM.002.2.11

* Corresponding Author. 


\section{PENDAHULUAN}

\section{Analisis situasi}

Undang-Undang Nomor 20 tentang sistem pendidikan nasional sebagai usaha sadar dan terencana untuk mewujudkan suasana belajar dan proses pembelajaran agar peserta didik secara aktif mengembangkan potensi dirinya untuk memilikikekuatan spiritual keagamaan, pengendalian diri, kepribadian, kecerdasan, akhlak mulia, serta ketrampilan yang diperlukan dirinya, masyarakat, bangsa dan negara. Pendidikan menengah terdiri atas pendidikan menengah umum dan pendidikan menengah kejuruan. Pendidikan kejuruan ditujukan untuk membentuk tenaga trampil tingkat menengah. Sekolah Menengah Kejuruan terdiri dari berbagai macam bidang keahlian. Penentuan jurusan atau program studi mengacu pada spektrum keahlian pendidikan menengah kejuruan yang diatur dengan Keputusan Direktur Jendral Manajemen Pendidikan Dasar Menengah Nomor 251/KEP/ $\mathrm{MN} / 2008$ tentang Spektrum Keahlan Pendidikan Menengah Kejuruan. Menurut keputusan tersebut terdapat 6 Bidang Studi Keahlian, 33 program keahlian dan 121 kompetensi keahlian.

Semua bidang keahlian di SMK memliki tujuan yang secara umum mengacu pada isi undang-undang sistem pendidikan nasional pasal 3 mengenai tujuan pendidikan nasional dan penjelasan pasal 15 yang menyebutkan bahwa pendidikan kejuruan merupakan pendidikan menengah yang mempersiapkan peserta didik terutama untuk bekerja pada bidang tertentu.Pendidikan kejuruan dibutuhkan untuk mendukung pertumbuhan industri di daerah tertentu. Strategi umum yang digunakan untuk menjamin keberhasilan dalam implementasi program-program pembinaan SMK dalam garis-garis besar pembinaan SMK salah satunya adalah penguatan sistem akreditasi program pendidikan dan penguatan sistem sertifikasi kompetensi lulusan, Strategi dan kebijakan tersebut merupakan fokus dari rencana strategis kemendiknas 2014 yaitu penerapan Kerangka Kerja Nasional Indonesia (KKNI) .

Sertifikasi kompetensi lulusan Sekolah Menengah Kejuruan disesuaikan dengan kebutuhan industri, artinya disiapkan sebagai tenaga kerja bidang indutri. Kompetensi tenaga kerja terbentuk dari tiga ranak (domain), yaitu ranah pengetahuan (kognitif), ranah ketrampilan (psikomotorik) dan ranah sikap (afektif). Tiga ranah itu masing-masing berkaitan dengan kemampuan daya pikir, kemampuan menggerakkan anggota badan dengan metode atau teknik tertentu, dan kemampuan mengekspresikan kemauan badan dengan metode atau teknik tertentu, dan kemampuan mengekspresikan kemauan diri. Secara ringkas, kompetensi dan tersebut didefinisikan sebagai penguasaan disiplin keilmuan dan pengetahuan serta ketrampilan menerapkan metode atau teknik tertentu yang didukung sikap perilaku yang tepat guna mencapai dan/atau mewujudkan hasil tertentu dalam penyelenggaran tugas pekerjaan.

Sebagai lembaga pendidikan maka 
sekolah menengah kejuruan harus bekerja berdasarkan SKKNI (Standar Kompetensi Kerja Nasional Indonesia). Standar Kompetensi Kerja Nasional Indonesia yang selanjutnya disingkat SKKNI adalah rumusan kemampuan kerja yang mencakup aspek pengetahuan, ketrampilan dan/atau keahlian serta sikap kerja yang relevan dengan pelaksanaan tugas dan syarat jabatan yang ditetapkan dengan ketentuan peraturan perundang-undangan yang berlaku. Pada tahun 2015 mulai diterapkan Undang-Undang Nomor 6 tahun 2014. Undang -Undang tersebut mengatur mengenai pengelolaan pemerintah desa. Desa diberikan kewenangan untuk mengolah sendiri semua kebutuhan yang menyangkut anggaran dan pendapatan belanja desa untuk kepentingan pembangunan dan kesejahteraan masyarakat desa. Desa akan mendapatkan kucuran dana sebesar kurang lebih satu milyar (Anggaran Pendapatan dan Belanja Negara).

\section{Menurut data Kementrian Dalam} Negeri dalam buku induk kode dan data wilayah administrasi pemerintahan per provinsi, kabupaten/kota dan kecamatan seluruh Indonesia tahun 2013 terdapat 72.944 wilayah administrasi desa dan 8.309 wilayah adminstrasi kelurahan. Sehingga total wilayah administrasi setingkat desa dan kelurahan sebanyak 81.253. Jumlah terbanyak, berada di Provinsi Jawa Tengah sebanyak 8.577 unit desa/kelurahan, sedangkan paling sedikit berada di Provinsi DKI Jakarta sebanyak 267 unit dan semuanya adalah administrasi kelurahan. Jika seluruh wilayah administrasi desa benar-benar telah dikucuri dana sebesar satu milyar, maka total anggaran yang ada mencapai hampir 80 triliun. Beberapa kalangan meragukan dan mengkhawatirkan pengelolaan dana yang begitu besar tersebut, meskipun dana tersebut berada di pemerintah kota dan kabupaten serta dilakukan pendampingan, termasuk penyusunan anggaran. Mengingat bahwa sumber daya manusia yang tersedia di tingkat desa yang menguasai pengelolaan anggaran dan pelaporannya amat sangat terbatas. Tak dapat dipungkiri bahwa rendahnya kualitas sumber daya manusia ini dapat dilihat dari persyaratan untuk menjadi seorang kepala desa minimal lulusan dari Sekolah Menengah Pertama sesuai dengan pasal 33 huruf d. Barangkali lulusan Sekolah Menengah Pertama memiliki kemampuan dalam kepemimpinan akan tetapi secara administratif akan lemah.

Kepala desa mempunyai tanggung jawab yang sangat besar dalam rangka tugas menyelenggarakan pemerintahan desa, melaksanakan pembangunan desa, pembinaan kemasyarakatan desa, dan pemberdayaan masyarakat desa. Dalam pelaksanaan tugas, kewenangan, hak dan kewajiban wajib untuk menyampaikan laporan penyelenggaran pemerintahan desa setiap akhir tahun, akhir masa jabatan kepada bupati atau walikota selain itu juga memberikan laporan keterangan penyelenggaran pemerintahan secara tertulis Badan Permusyawaratan Desa dan masyarakat desa setiap akhir tahun anggaran. Pengelolaan dana tersebut memerlukan pertanggungjawaban secara 
administratif, oleh sebab itu setiap desa hendaknya memiliki sumber daya manusia yang menguasai akuntansi setidaknya pembukuan agar pemakaian dana tersebut dapat dipertanggungjawabkan.

Bukan hanya kepala desa saja yang mesti menguasai akuntansi karena kepala desa merupakan jabatan politis dan ada jangak waktu jabatan yang diemban sedangkan Undang-Undang tersebut akan berlaku panjang maka diperlukan sumber daya secara mandiri yang akan terus bekerja mesti berganti kepala desa. Jika dari sisi data akuntansi tidak valid maka dikhawatirkan akan banyak kepala desa tersandung masalah dengan tuduhan korupsi akibat ketidakmampuan aplikasi akuntansi dalam pengelolaan keuangan desa. Dana yang akan dikelola pemerintah desa harus dibuat anggaran dan pelaporannya oleh tenaga kerja yang kompeten bidang akuntansi, terutama akuntansi pemerintah. Sekolah Menengah Kejuruan (SMK) harus mampu merespon perubahan kebijakan pemerintah tersebut. Jelas ada celah yang masih bisa dimanfaatkan oleh SMK khususnyakelompok keahlian bisnis dan manajemen untuk menghasilkan tenaga kerja seperti pada Bidang Akuntansi pemerintahan, perlu adanya hubungan timbal balik antara pihak-pihak yang berkepentingan sebagai pengguna tenaga kerja, dengan pihak pendidikan dan latihan formal maupun non formal yang menghasilkan tenaga kerja. Kerja sama tersebut untuk merumuskan standar kualifikasi tenaga kerja sehingga bisa dihasilkan tenaga kerja yang diinginkan stakeholder yaitu mampu membuat laporan keuangan. Sekolah Menengah Kejuruan (SMK) khususnya kelompok keahlian bisnis dan manajemen dapat berperan aktif dalam menghasilkan tenaga operator akuntansi untuk memenuhi kebutuhan tenaga administrasi pemerintahan daerah dan desa. Peran aktif SMK berupa penambahan penyampaian meteri kompetensi akuntans pemerintah sehingga lulusan dapat terserap di pemerintah daerah dan desa.

\section{Perumusan masalah}

a. Apakah guru pengampu mata ajar memahami kompetensi umum dan kompetensi inti mata pelajaran akuntansi pemerintah?.

b. Apakah guru pengampu mata ajar akuntansi pemerintah bisa menghasilkan suatu konsep pemahaman yang memadai untuk diberikan kepada anak didiknya?

c. Apakah guru mata ajar memilik catatan yang komprehensif dapat dijadikan evaluasi untuk memprediksi proses pembelajarannya sehingga dapat dipahami oleh peserta didik dan menjadikan mereka sebagai tenaga administrasi yang siap terjun di lapangan ketika lulus nanti?

\section{Tujuan, dan manfaat pengabdian kepada masyarakat}

a. Meningkatkan pemahaman guru SMK dalam memahami kompetensi Dasar dan Kompetensi inti materi akuntansi pemerintah.

b. Menyiapkan bahan ajar yang dapat dipahami oleh peserta didik dalam hal 
pengetahuan dan praktek.

c. Meningkatkan kemampuan guru dalam proses pencatatan dan pelaporan keuangan akuntansi pemerintah daerah dan desa.

\section{KAJIAN TEORITIK}

Akuntansi Pemerintahan dapat didefinisikan sebagai suatu aktivitas pemberian jasa untuk menyediakan informasi keuangan pemerintah berdasarkan proses pencatatan, pengklasifikasian, pengikhtisaran, suatu transaksi keuangan pemerintah serta penafsiran atas informasi keuangan. Dengan demikian secara umum pengertian tersebut tidak berbeda dengan akuntansi, perbedaannya terletak pada jenis transaksi yang dicatat dan penggunanya. Jenis yang dicatat dalam akuntansi pemerintah adalah transaksi keuangan pemerintah. Penggunanya secara umum adalah rakyat secara luas yang diwakili oleh lembaga legislative, pemerintah dan kreditor seperti: IMF, ADB dan yang lainnya.

Tujuan Pemerintah dan Karakteristik Akuntansi Pemerintahan

Pemerintah sebagai salah satu bentuk organisasi sektor publik memilik tujuan umum untuk menyejahterakan rakyat. Untuk mewujudkan hal tersebut rakyat membuat aturan umum yang harus dipenuhi pemerintah berupa konstitusi atau undang-undang dasar dan peraturan perundang-undangan lainnya. Oleh karena itu, adanya perbedaan perlakuan akuntansi pemerintahan dengan akuntansi bisnis dalam hal tujuan serta pengukuran kinerjanya. Meskipun tujuan kedua organisasi berbeda tetapi pada hakikatnya tujuan akuntansi pemerintahan dan akuntansi bisnis sama yaitu memberikan informasi keuangan atas transaksi keuangan yang dilakukan organisasi tersebut pada periode tertentu.

Berkenaan dengan itu, akuntansi pemerintahan dan akuntansi bisnis secara khusus memiliki tujuan berikut:

1. Akuntabilitas

Fungsi akuntabilitas lebih luas dari sekedar ketaatan kepada peraturan perundangan yang berlaku, tetapi tetap memperhatikan penggunaan sumber daya secara bijaksana, efisien, efektif dan ekonomis.

\section{Manajerial}

Akuntansi pemerintah memungkinkan pemerintah untuk melaksanakan fungsi manajerial dengan melakukan perencanaan berupa penyusunan $\mathrm{APBN}$ dan strategi pembangunan lain.

\section{Pengawasan}

Akuntansi pemerintahan dibuat untuk memungkinkan diadakannya pengawasan pengurusan keuangan Negara dengan lebih mudah oleh aparat pemeriksa seperti BPKRI.

Karakteristik akuntansi pemerintahan Karakteristik akuntansi pemerintahan berbeda dengan akuntansi bisnis, perbedaannya seperti:

1. Dalam akuntansi pemerintahan tidak ada laporan laba

2. Pemerintah membukukan anggaran ketika anggaran tersebut dibukukan

3. Akuntansi pemerintahan bias 
menggunakan lebih dari satu jenis dana

4. Akuntansi pemerintahan akan membukukan pengeluaran modal dalam perkiraan neraca dan hasil operasional.

5. Akuntansi pemerintahan bersifat kaku karena sangat bergantung pada peraturan perundang-undangan.

6. Di dalam akuntansi pemerintahan tidak ada perkiraan modal dan laba ditahan di dalam neraca.

Meskipun ada perbedaan, akuntansi pemerintahan tetap memiliki kesamaan dengan akuntansi bisnis yaitu:

1. Memberikan informasi atas posisi keuangan dan hasil operasi.

2. Mengikuti prinsip-prinsip dan standar akuntansi yang diterima umum.

3. Bersama-sama mengembangkan prinsipprinsip dan standar akuntansi.

4. Menggunakan system bagan perkiraan standar.

\section{Ruang Lingkup Akuntansi Pemerintah}

Perkembangan akuntansi pemerintahan tidaklah secepat akuntansi bisnis. Penyebabnya adalah karakteristiknya tidak banyak mengalami perubahan. Dengan adanya tuntutan masyarakat menyebabkan akuntansi pemerintahan menjadi penting. Semakin besarnya dana yang dikelola oleh pemerintah semakin besar pula tuntutan akuntabilitas keungan sebagai wujud transparasi keuangan dalam pemerintahan.

Pemerintah sebagai salah satu bentuk organisasi sector public memilik tujuan umum untuk menyejahterakan rakyat. Untuk mewujudkan hal tersebut rakyat membuat aturan umum yang harus dipenuhi pemerintah berupa konstitusi atau undang-undang dasar dan peraturan perundang-undangan lainnya.

Oleh karena itu, adanya perbedaan perlakuan akuntansi pemerintahan dengan akuntansi bisnis dalam hal tujuan serta pengukuran kinerjanya. Meskipun tujuan kedua organisasi berbeda tetapi pada hakikatnya tujuan akuntansi pemerintahan dan akuntansi bisnis sama yaitu memberikan informasi keuangan atas transaksi keuangan yang dilakukan organisasi tersebut pada periode tertentu. Akuntansi pemerintah merupakan proses pendokumentasian,pencatatan, pengikhtisaran dan pelaporan transaksi-transaksi keuangan pemerintah, baik ditingkat pusat maupun di daerah. Reformasi keuangan pemerintah dimulai dengan munculnya undang-undang undang keuangan negara yang mewajibkan pemerintah untuk menyusun laporan keuangan. Pada awalnya,akuntansi pemerintah baru diimplementasikan pada pemerintah pusat saja, seiring dengan kebutuhan akuntabilitas keuangan pemerintah, akuntansi pemerintah berkembang ke pemerintah pusat hingga pemerintah daerah hingga desa. UU No 6 tahun 2014 mengatur mengenai pengelolaan pemerintah Desa. Berdasarkan undang-undang tersebut, desa diberikan alokasi dana APBN dan memiliki kewenangan untuk mengelola kebutuhan wilayahnya yang menyangkut pendapatan dan belanja dalam rangka melaksanakan program-program 
pembanguan Desa.

Menyikapi pertanggungjawaban anggaran tersebut, dilakukan penetapan standar kualifikasi tenaga kerja seperti pada bidang akuntansi pemerintah, perlu adanya hubungan timbal balik antara pihak-pihak yang berkepentingan sebagai pengguna tenaga kerja, dengan pihak pendidikan dan latihan formal maupun non formal yang menghasilkan tenaga kerja. Kerja sama tersebut untuk merumuskan standar kualifikasi tenaga kerja sehingga bisa dihasilkan tenaga kerja yang diinginkan oleh stkeholder yaitu mampu membuat laporan keuangan. Sekolah Menengah Kejuruan (SMK), khususnya kelompok keahlian bisnis dan manajemen dapat berperan aktif dalam menghasilkan tenaga operator akuntansi untuk memenuhi kebutuhan tenaga administrasi pemerintah daerah dan desa. Peran aktif SMK berupa penambahan penyampaian materi kompetensi akuntansi pemerintah, sehingga lulusannya dapat terserap di pemerintah daerah dan desa.

\section{Ciri Keuangan Pemerintah Daerah}

Laporan keuangan pemerintah daerah meru pakan keluaran (output) dari sistem akuntansi keuangan pemrintah daerah, sedangkan sistem akuntansi dikembangkan sesuai dengan kegiatan pengelolaan keuangan berdasarkan peraturan perundang-undangan yang berlaku. Lingkungan operasional organisasi pemerintah daerah berpengaruh terhadap karakteristik tujuan akuntansi dan pelaporan keuangan pada pemerintah daerah. Ciri keuangan pemerintah daerah yang perlu dpertimbangkan dalam menetapkan tujuan akuntansi dan pelaporan keuangan antara lain meliputi :

1. Sistem Penganggaran Pemerintah
Daerah

Anggaran pemerintah merupakan dokumen formal hasil kesepakatan antara eksekutif dan legislatif tentang belanja yang ditetapkan untuk melaksanakan kegiatan pemerintah dan pendapatan yang diharapkan untuk menutup kepeluan belanja tersebut atau pembiayaan yang diperlukan bila diperkirakan akan terjadi defisit atau surplus. Dengan demikian, fungsi anggaran di lingkungan pemerintah mempunyai pengaruh yang penting antara lain karena :

a. Anggaran merupakan pernyataan kebijakan public.

b. Anggaran merupakan target fiscal yang menggambarkan keseimbangan antara belanja, pendapatan, dan pembiayaan yang diinginkan.

c. Enggaran menjadi landasan pengendalian yang memiliki konsekuensi hokum.

d. Anggaran memberi landasan penilaian kinerja pemerintah.

e. Hasil pelaksanaan anggaran dituangkan dalam laporan keuangan pemerintah sebagai pernyataan pertanggungjawaban pemerintah kepada publik..

Atas pertimbangan ini maka sistem penganggaran pada pemerintah daerah akan sangat berpengaruh dalam pengembangan sisten akuntansi keuangan pemerintah daerah dan dalam penyusunan laporan keuangan. Realisasi atas belanja, pendapatan dan 
pembiayaan yang telah dianggarkan dilaporkan dalam Laporan Realisasi Anggaran (LRA). Dalam hal anggaran disusun dan dilaksanakan berdasarkan basis kas, maka Laporan Realisasi Anggaran (LRA) disusun berdasarkan basis kas, sedangkan bila anggaran disusun berdasarkan basis akrual, maka LRA pun disusun berdasarkan basis akrual.

2. Investasi dalam Aset yang Tidak Langsung Menghasilkan Pendapatan

Investasi yang ditanamkan oleh suatu organisasi selalu diharapkan dapat memberikan hasil yang sebanding dengan pengorbanan yang telah dikeluarkan. Di dalam organisasi nirlaba seperti pemerintahan, hal ini tidak dapat dilakukan mengingat tujuan dan fungsi dari pemerintahan itu sendiri. Pemerintah daerah adalah organisas yang mempunyai tugas dan fungsi memberi layanan kepada masyarakat pada setiap kegiatan operasional yang dilakukannya.

3. Penggunaan Akuntansi Dana

Akuntansi dana (fund accounting) merupakan sistem akuntansi dan pelaporan keuangan yang lazim diterapkan di lingkungan pemerintah yang memisahkan kelompok dana menurut tujuannya, sehingga masng-masing merupakan entitas akuntansi yang mampu menunjukkan keseimbangan antara belanja dan pendapatan atau transfer yang diterima. Akuntansi dana dapat diterapkan untuk tujuan pengendalian masing-masing kelompok dana selan kelompok dana umum (the general fund) sehingga perlu dipertimbangkan dlaam pengembangan pelaporan keuangan pemerintah.

\section{Penyusutan Aset Tetap}

Penyusutan adalah alokasi yang sistematis atas nilai suatu aset tetap yang dapat disusutkan (depreciable assets) selama masa manfaat aset yang bersangkutan. Pencatatan penyusutan ini merupakan salah satu penanda pemberlakuan basis akrual dalam standar akuntansi pemerintah. Aset yang digunakan pemerintah, kecuali beberapa jenis aset tertentu seperti tanah mempunyai masa manfaat dan kapasitas yang terbatas. Seiring dengan penurunan kapasitas dan manfaat dari suatu aset dilakukan penyesuaian nilai. Penyesuaian nilai aset tetap dilakukan dengan berbagai metode yang sistematis sesuai dengan masa manfaat. Metode penyusutan yang digunakan harus dapat menggambarkan manfaat ekonomi atau kemungkinan jasa (service potential) yang akan mengalir ke pemerintah.

Pengguna Laporan Keuangan dan Kebutuhan Informasi yang Diperlukan

Pengguna laporan keuangan pemerintah daerah tidak terbatas pada masyarakat, wakil rakyat, lembaga pengawas, lembaga pemeriksa, pihak yang memberi atau berperan dalam proses donasi, investasi dan pinjaman, tetapi juga pemerintah itu sendiri. Informasi yang disajikan dalam laporan keuangan bertujuan umum untuk memenuhi kebutuhan informasi dari semua kelompok pengguna. Kebutuhan informasi tentang kegiatan operasional pemerintah serta posisi kekayaan dan kewajiban dapat dipenuhi dengan lebih baik dan memadai apabila 
didasarkan pada basis akrual, yakni berdasarkan pengakuan munculnya hak dan kewajiban, bukan berdasarkan pada arus kas semata.

Entitas Akuntansi dan Pelaporan pada Pemerintah Daerah

Sesuai dengan definisi dalam PSAP 01 paragraf 8, Entitas Akuntansi adalah unit pemerintahan pengguna anggaran pengguna barang dan oleh karenanya wajib menyelenggarakan akuntansi dan menyusun laporan keuangan untuk digabungkan pada entitas pelaporan. Dengan demikian entitas akuntansi dapat dikatakan sebagai unit pada pemerintahan yang mengelola anggaran, kekayaan dan kewajiban yang menyelenggarakan akuntansi dan menyajikan laporan keuangan berdasarkan akuntansi yang diselenggarakannya. Berdasarkan definis di atas maka entitas akuntansi pada pemerintah daerah adalah Satuan Kerja Perangkat Daerah (SKPD). Terkait dengan Badan Layanan Umum Daerah (BLUD), pada praktiknya ada yang berstatus sebagai SKPD maupun unit di bawah SKPD, tergantung pada kebijakan pemerintah daerah yang bersangkutan.

Entitas pelaporan adalah unit pemerintahan yang terdiri atas satu atau lebih entitas akuntansi atau entitas pelaporan yang menurut ketentuan peraturan perundangundangan wajib menyampaikan laporan pertanggungjawaban berupa laporan keuangan. Oleh sebab itu, dalam penetapan entitas pelaporan, perlu dipertimbangkan syaratpengelolaan, pengendalian dan penguasaan entitas pelaporan terhadap aset, yurisdiksi, tugas dan misi tertentu, dengan bentuk pertanggungjawaban dan wewenang yang terpisah dari entitas pelaporan lainnya. Dengan pertimbangan tersebut maka entitas pelaporan pemerintah daerah adalah pemerintah provinsi/kabupaten/kota.

Sistem dan Pelakuan Akuntansi

Untuk menyusun dan menyajikan laporan keuanga pemerintah daerah diperlukan suatu sistem akuntansi yang dapat mengakomodasi kebutuhan informasi atas pengelolaan keuangan daerah. Sistem akuntansi pemerintah sesuai dengan PP Nomor 71 tahun 2010 paal 1 angka 11 adalah rangkaian sistematik dari prosedur, penyelenggara, peralatan dan elemn lain untuk mewujudkan fungsi akuntansi sejak analisis transaksi sampai dengan pelaporan keuangan di lingkungan organisasi pemerintah.

Dengan kata lain, sistem akuntansi merupakan serangkaian prosedur mulai dari proses pengumpulan data, pencatatan, pengklasifikasian, pengikhtisaran sampai dengan pelaporan keuangan dalam rangka pertanggungjawaban pelaksanaan Anggaran Pendapatan dan Belanja Daerah (APBD) yang dapat dilakukan secara manual ataupun dengan menggunakan aplikasi komputer. Untuk dapat melakukan penyusunan sistem akuntansi yang emmadai dan sesuai dengan kebutuhan pemerintah daerah maka beberapa faktor penting perlu diperhatikan. Faktor-faktor yang 
perlu diperhatikan dalam menyusun sistem akuntansi tersebut adalah sebagi berikut :

\section{Basis Akuntansi}

Basis akuntansi merupakan salah satu prinsip akuntansi dan pelaporan keuangan yang dimaksudkan sebagai ketentuan yang dipahami dan ditaati oleh pembuat standar dalam menyusun standar, penyelenggara akuntansi dan pelaporan keuangan dalam melakukan kegiatannya, serta pengguna laporan keuangan dalam memahami laporan keuangan yang disajikan. Pengakuan Unsur Laporan Keuangan Pengakuan dalam akuntansi adalah proses penetapan terpenuhinya kriteria pencatatan suatu kejadian atau peristiwa dalam catatan akuntansi sehingga akan menjjadi bagian yang melengkapi unsur aset, kewajiban, ekuitas, pendapatan-LRA, belanja, pembiayaan, pendapatan-LO dan beban, sebagaimana akan termuat pada laporan keuangan entitas pelaporan yang bersangkutan. Pengakuan diwujudkan dalam pencatatan jumlah uang terhadap pos-pos laporan keuangan yang terpengaruh oleh kejadian atau peristiwa terkait.

Faktor ini akan terkait erat dengan penatausahaan keuangan termasuk dokumendokumen yang akan digunakan. Misalnya, mengenai pengakuan pendapata-LO. Dalam standar akuntansi pemerintah pengakuan pendapatan-LO mempunyai karakteristik sebagai berikut :

a. Pendapatan-LO yang diperoleh berdasarkan peraturan perundang-undangan diakui pada saat tibulnya hak untuk menagih pendapatan.

b. Pendapatan-LO yang diperoleh sebagai imbalan atas suatu pelayanan yang telah selesai diberikan berdasarkan peraturan perundang-undangan, diakui pada saat timbulnya hak untuk menagih imbalan;

c. Pendapatan-LO yang diakui pada saat direalisasi adalah hak yang telah diterima oleh pemerintah tanpa terlebih dahulu adanya penagihan; dan

d. Dalam hal instansi pemerintah berbentuk Badan Layanan Umum (BLU) pendapatan diakui dengan mengcu kepada perundangundangan yang mengatur mengenai BLU.

Atas dasar karakteristik tersebut diatas, maka timbulnya hak untuk ditagih maupun hak yang telah diterima akan terkait dengan terbitnya suatu dokumen di dalam proses penatausahaan keuangan. Sebagai contoh transaksi untuk hak untuk ditagih yang akan diakui misalnya saat dokumen Surat Ketetapan Pajak (SKP) terbit. Saat dokumen ini terbit, maka hak tagih atas pendapatan timbul sehingga atas pendapatan tersebut harus segera dilakukan.

\section{Pengukuran}

Pengguna laporan keuangan perlu mengetahui dasar-dasar pengukuran yang digunakan sebagai landasan dalam penyajian laporan keuangan. Apabila lebih dari satu dasar pengukuran digunakan dalam penyusunan laporan keuangan, maka informasi yang disajikan harus cukup memadai untuk mengindikasikan unsur laporan keuangan yang menggunakan dasar pengukuran tersebut. Oleh sebab itu, faktor pengukuran akan menjadi faktor penting yang harus diperhatikan dalam penyusunan suatu sistem akuntansi. Pengakuan dan pengukuran merupakan dua hal yang saling 
terkait. Kriteria pengakuan pada umumnya didasarkan pada nila uang akibat peristiwa atau kejadian yang dapat diandalkan pengukurannya. Namun ada kalanya pengakuan didasarkan pada hasil estimasi yang layak. Apabila pengukuran berdasarkan biaya dan estimasi yang layak tidak mungkin dilakukan, maka pengakuan transaksi demikian cukup diungkapkan pada Catatan Atas laporan keuangan.

\section{Pengungkapan}

Pernyataan Nomor 01 Standar Akuntansi Pemerintah (PSAP 01) paragraf 25 PP Nomor 71 tahun 2010 mensyaratkan adanya pengungkapan tertentu pada lembar muka (on the face) laporan keuangan, mensyarakan pengungkapan pos-pos lainnya dalam lebar muka laporan keuangan atau dalam Catatan atas laporan keuangan, dan merekomendasikan format ilustrasi yang dapat diikut oleh suatu entitas pelaporan sesuai dengan situasi masingmasing.

Sebagai contoh pengungkapan pos dalam laporan keuangan adalah pengungkapan pos-pos neraca. Contoh pengungkapan ini akan bervariasi untuk setiap pos, misalnya :

a. Piutang dirinci menurut jumlah piutang pajak, retribusi, penjualan, pihak terkait, uang muka dan jumlah lainnya; piutang transfer dirinci menurut sumbernya.

b. Persediaan dirinci lebih lanjut sesuai dengan standar yang mengatur akuntansi untuk persediaan.

c. Aset tetap diklasifikasikan berdasarkan kelompok sesuai dengan standar yang mengatur tentang aset tetap.

d. Utang transfer dianalisis menurut entitas penerimanya.

e. Dana cadangan diklasifikasikan sesuai dengan peruntukannya.

f. Pengungkapan kepentingan pemerintah dalam perusahaan negara/daerah lainnya adalah jumlah penyertaan yang diberikan, tingkat pengendalian dan metode penilaian.

\section{Periode Pelaporan}

Laporan keuangan disajikan sekurangkurangnya sekali dalam setahun. Dalam situasi tertentu, misalnya sehubungan dengan adanya perubahan tahun anggaran, tanggal laporan suatu entitas berubah dan laporan keuangan tahunan disajikan dengan suatu periode yang lebih panjang atau lebih pendek dari satu tahun. Apabila laporan keuangan disajikan dengan suatu periode yang lebih panjang atau lebih pendek dari satu tahun, entitas pelaporan perlu mengungkapkan informasi berikut :

a. Alasan penggunaan periode pelaporan tidak satu tahun,

b. Fakta bahwa jumlah-jumlah komparatif untuk laporan tertentu seperti arus kas dan catatan-catatan terkait tidak dapat diperbandingkan.

\section{Pencatatan}

Pencatatan merupakan bagian dari proses akuntansi yang pengertiannya adalah suatu kegiatan mencatat/merekam pos-pos laporan keuangan yang terpengaruh oleh suatu transaksi/kejadian keuangan setelah adanya pengakuan dan pengukuran atas transaksi dan kejadian keuangan tersebut. 
Tujuan Pelaporan Keuangan Pemerintah Daerah

1. Tujuan Umum Pelaporan Keuangan

Laporan keuangan untuk tujuan umum juga mempunyai peranan prediktif dan prspektif, menyediakan informasi yang berguna untuk memprediksi besarnya sumber daya yang dibutuhkan untuk operasi yang berkelanjutan, serta resiko dan ketidakpastian yang terkait. Pelaporan keuangan juga menyajikan informasi bagi pengguna mengenai :

a. Indikasi apakah sumber daya yang telah diperoleh dan digunakan sesuai dengan anggaran; dan

b. Indikasi apakah sumber daya yang diperoleh dan digunakan sesuai dengan ketentuan, termasuk batas anggaran yang ditetapkan oleh DPR/DPRD.

\section{Tujuan Khusus Pelaporan Keuangan}

Perbedaan laporan yang harus dibuat oleh pemerintah daerah menurut PP Nomor 24 tahun 2005 dan PP nomor 71 tahun 2010, laporan keuangan yang perlu tujuan khusus dari pelaporan keuangan sesuai dengan jenis laporannya dapat diuraikan sebagai berikut :

a. Menyediakan informasi tentang sumber, alokasi dan penggunaan sumber daya keuangan yang disajikan LRA;

b. Menyediakan informasi mengenai kecukupanpenerimaan periode berjalan untuk membiayai seluruh pengeluaran yang disajikan dalam LRA dan LAK.

c. Menyediakan informasi mengenai jumlah sumber daya ekonomi yang digunakan dalam kegiatan entitas pelaporan serta hasilhasil yang telah dicapai yang disajikan dalam Neraca dan LRA. d. Menyediakan informasi mengenai bagaimana entitas pelaporan mendanai seluruh kegiatannya dan mencukupi kasnya yang disajikan dalam LRA dan LAK.

e. Menyediakan informasi mengenai posisi keuangan dan kondisi entitas pelaporan berkaitan dengan sumber-sumber penerimaannya, baik jangka pendek maupun jangka panjang, termasuk yang berasal dari pungutan pajak dan pinjaman yang disajikan dalam Neraca dan Laporan Perubahan Ekuitas.

f. Menyediakan informasi mengenai perubahan posisi keuangan entitas pelaporan, apakah mengalami kenaikan atau penurunan, sebagai akibat kegiatan yang dilakukan selama periode pelaporan yang disajikan dalam Neraca dan Laporan Perubahan Ekuitas.

g. Menyajikan informasi kenaikan atau penurunan saldo anggaran lebih tahun pelaporan dibandingkan dengan tahun sebelumnya yang disajkan dalam Laporan Perubahan Saldo Anggaran Lebih.

h. Menyajikan ikhtisar sumber daya ekonomi yang menambah ekuitas dan penggunaannya yang dikelola oleh pemerintah daerah untuk kegiatan penyelenggaraan pemerintahan dalam satu periode pelaporan yang disajikan dalam Laporan Operasional.

i. Menyediakan penjelasan naratif atau rincian dari angka yang tertera dalam laporan keuangan dan informasi tentang 
kebijakan akuntansi yang dipergunakan oleh entitas pelaporan dan informasi lain yang diharuskan dan dianjurkan untuk diungkapkan di dalam Standar Akuntansi Pemerintah serta ungkapan-ungkapan yang diperlukan untuk menghasilkan penyajian laporan keuangan secara wajar yang disajikan dalam Catatan Atas Laporan Keuangan.

\section{MATERI DAN METODE}

\section{Kerangka Pemecahan Masalah}

Berdasarkan permasalahan yang dihadapi oleh para guru tersebut, maka kerangka pemecahan masalah yang ditawarkan adalah sebagai berikut:

a. Pelatihan pemahaman dan keterampilan mengenai gambaran umum akuntansi pemerintah terutama konsep dasar akuntansi pemerintah serta dokumendokumen yang disiapkan, bertujuan:

1. Kemampuan kelompok sasaran meningkat $85 \%$ dalam bidang pengetahuan dan keterampilan dalam penyusunan laporan keuangan pemerintah pusat maupun daerah.

2. Kelompok sasaran mampu membedakan dan menyiapkan dokumen dalam penyusunan laporan baik pemerintah daerah maupun desa

b. Peningkatan kemampuan SDM dalam bidang pencatatan dan pelaporan akuntansi pemerintah daerah, dengan tujuan:

1. Peningkatan kemampuan SDM dalam bidang pencatatan akuntansi pemerintah daerah sebesar $80 \%$.
2. Peningkatan kemampuan SDM dalam bidang pelaporan keuangan pemerintah daerah sebesar $75 \%$.

c. Peningkatan kemampuan SDM dalam bidang pencatatan dan pelaporan akuntansi desa, dengan tujuan:

1. Kemampuan kelompok sasaran meningkat dalam bidang pecatatan akuntansi desa sebesar $80 \%$.

2. Kemampuan kelompok sasaran meningkat dalam bidang pelaporan keuangan desa sebesar $75 \%$.

\section{Realisasi Pemecahan Masalah}

Realisasi pemecahan masalah melalui beberapa pelaksanaan kegiatan sebagai berikut:

1. Hari ke - 1 (Gambaran Umum Akuntansi Pemerintah)

Materi: Gambaran Umum Akuntansi Pemerintah (menjelaskan onsep dasar akuntansi pemerintah dan siklus akuntansi pemerintah serta dokumen-dokumen yang terkait).

Proses Pembelajaran: peserta akan diajari teknik dasar pengenalan Akuntansi Pemerintah dan Anggaran dengan memberikan contoh kasus latihan.

2. Hari ke -2 (Pencatatan dan Pelaporan Keuangan Pemerintah Desa)

Materi: Pengenalan tentang pencatatan dan pelaporan keuangan pemerintah desa.

Proses Pembelajaran: peserta sebelumnya di jelaskan terlebih teori dan praktik pencatatan dan pelaporan keuangan pemerintah desa. 
3. Hari ke -3 (Pencatatan dan Pelaporan Keuangan Pemerintah Daerah)

Materi: Pengenalan tentang pencatatan dan pelaporan keuangan pemerintah daerah.

Proses Pembelajaran: peserta sebelumnya di jelaskan terlebih teori dan praktik pencatatan dan pelaporan keuangan daerah

\section{Khalayak Sasaran}

Khalayak dan sasaran dari ini adalah guru SMK pengampu mata pelajaran akuntansi yang ada wilayah Jakarta Timur dan Bekasi, kurang lebih 41 orang. Peserta kegiatan ini didominasi oleh peserta perempuan, yang terdiri lebih dari $50 \%$ peserta. Mayoritas peserta berasal dari SMK swasta, karena SMK negeri di Jakarta Timur hanya 3 SMK yang memiliki prodi bisnis dan produktif. Sebagian besar peserta belum memiliki pemahaman tentang akuntansi pemerintah daerah dan desa, karena pada saat perkuliahan materi yang diajarkan sebagian besar mengenai akuntansi pemerintah pusat.

\section{Metode}

Metode yang digunakan dalam kegiatan program pelatihan ini adalah metode Ceramah dan Diskusi. Metode penjelasan dari instruktur berupa teori tentang konsep pelaporan keuangan serta memberikan latihan dan praktik pembuatan laporan keuangan dengan meminta peserta mengisi sesuai dengan kondisi penerimaan dan pengeluaran kas peserta pelatihan. Pada Metode Penjelasan, setiap instruktur menyampaikan materi terkait selama 4 jam kemudian dilanjutkan dengan sesi tanya jawab selama 30 - 45 menit. Setelah makan siang dilanjutkan dengan simulasi pelatihan pembuatan laporan keuangan pemerintah daerah dan desa.

\section{HASIL DAN PEMBAHASAN}

Kegiatan PKM ini bermitra dengan MGMP Jakarta Timur, dilaksanakan di SMKN 51 diruang pertemuan lantai 2 yang beralamat di Jalan Bambu Apus Raya no. 40,Rt.06/Rw.03, Bambu Apus Cipayung, Kota Jakarta Timur, DKI Jakarta 13890. Peserta kegiatan ini merupakan anggota MGMP Jakarta Timur dan beberapa Guru dari Bekasi yang mengampu mata pelajaran akuntansi pemerintahan, yang terdiri kurang lebih 43 orang Guru. Pelaksanakan PKM dilakukan selama tiga hari, yaitu mulai dari tanggal 8 Agustus hingga 10 Agustus,2018. Waktu pelaksanaan kegiatan dari pukul 8.00 WIB- 15.00 WIB. Dengan izin Allah PKM ini dapat berjalan lancar dari hari pertama hingga penutupan. Adapun pelaksanaan kegiatan tersebut adalah sebagai berikut :

a. Kegiatan hari pertama

Kegiatan hari pertama dimulai dengan sambutan oleh Wakil Kepala Sekolah SMKN 51 sekaligus membuka acara, dan Sambutan dari Perwakilan MGMP Jakarta timur. Kegiatan ini diikuti guru akuntansi pemerintahan se Jaktim dan sebagian dari Bekasi. Pada hari pertama dilakukan pre test mata pelajaran akuntansi pemerintahan. Nilai rata-rata hasil post tes adalah 54,8 , kemudian dilanjutkan dengan materi yang disampaikan 
oleh Ibu Ratna Anggraini SE, Msi, Ak, CA mengenai pengantar akuntansi pemerintahan. Pada siang hari setelah istirahat, materi dilanjutkan oleh Bapak Ahmad Fauzi, SPd.MAk, tentang siklus akuntansi dan praktik jurnal akuntansi pemerintahan.

b. Kegiatan Hari Kedua

Kegiatan hari kedua langsung dimulai dengan materi akuntansi desa, yang disampaikan oleh Ibu Tri Hesti U, SE, MSA. Pada siang harinya lakukan praktik akuntansi desa, berupa penyelesaian kasus-kasus pembukuan di transaksi desa. Pada hari kedua ini, tim dari Lemlit UNJ melakukan evaluasi kelapangan mengenai pelaksanaan kegiatan PKM.

\section{c. Kegiatan Hari Ketiga}

Pada hari ketiga, diawali dengan materi Akuntansi Pemerintah Daerah oleh Ibu Nuramalia Hasanah, kemuadian pada siang hari setelah istirahat diadakan praktik membahas transaksi akuntansi pemerintah daerah. Di akhir sesi diadakan post test dan evaluasi kegiatan. Dari hasil post test dapat diketahui terjadi peningkatan nilai rata-rata peserta menjadi 60,8 .

Dari kegiatan ini dapat diketahui ada peningkatan kemampuan peserta untuk memahami akuntansi pemerintah hal ini dapat dilihat dari perbandingan hasil pre test dan post test, yang menunjukkan ada peningkatan sekitar 10\%. Hasil ini memang belum begitu memuaskan, hal ini disebabkan karena materi yang diajarkan cukup banyak, dan sebagian besar peserta belum pernah mendapatkan materi tersebut karena merupakan materi yang baru.
Dari hasil evaluasi pelatihan ini dapat dketahui bahwa sekitar $89,75 \%$ peserta menjawab materi yang disampaikan sudah sesuai dengan kebutuhan, 84,66\% peserta merasa terdapat kesesuaian bahan ajar, 100\% peserta merasa bahan tayang yang diberikan sangat bermanfaat, meskipun untuk bahan latihan kepuasan peserta masih kurang, yaitu sekitar $70 \%$, hal ini karena kendala waktu latihan yang terbatas.Untuk sarana dan prasarana pelatihan $100 \%$ peserta menjawab sarana pelatihan sudah sesuai dan 97\% peserta menjawab prasarana pelatihan sudah sesuai.

\section{KESIMPULAN DAN SARAN}

\section{Kesimpulan}

a. Terdapat peningkatan pemahaman guru SMK mata pelajaran akuntansi terkait kompetensi dasar dan kompetensi inti materi akuntansi pemerintah.

b. Para guru pengampu mata pelajaran akuntansi pemerintah dapat menyiapkan bahan ajar yang dapat dipahami oleh peserta didik dalam hal pengetahuan dan praktek.

c. Terdapat peningkatan kemampuan guru dalam proses pencatatan dan pelaporan keuangan akuntansi pemerintah daerah dan desa.

\section{Saran}

Beberapa saran dari kegiatan ini antara lain:

1. Diadakan pelatihan tindak lanjut untuk ke depannya, agar materi dapat tercakup seluruhnya, khususnya yang berhubungan 
dengan aplikasi sistem melalui perangkat lunak.

2. Memperbanyak menggunakan metode studi kasus, agar peserta dapat lebih paham terkait materi yang disampaikan.

3. Untuk diklat selanjutnya tentang workshop sistem aplikasi keuangan desa.

\section{DAFTAR PUSTAKA}

Arif, Bahtiar. dkk. (2002). Akuntansi Pemerintahan. Jakarta : Salemba Empat.

Baldric dan Bonni Siregar. (1996). Akuntansi Pemerintahan dengan Sistem Dana, Edisi

2. STIE YKPN: Yogyakarta.

Baswir, Revrisond. (1992). Akuntansi Pemerintahan Indonesia. Yogyakarta : BPFE Yogyakarta.

Hessel Nogi D.Tangkilisan. (2005). Manajemen Publik.. Jakarta : Grasindo.

Hasanah Nuramalia dkk. (2016). Akuntansi Pemerintah. Jakarta : In Media.

Ikatan Akuntansi Indonesia. (2005). Standar Akuntansi Pemerintahan. Jakarta: Komite Standar Akuntansi Pemerintahan.

Nordiawan, Deddi, Iswahyudi S.P., Maulidah R. (2007). Akuntansi Pemerintah. Jakarta: Salemba Empat,.
Akuntansi Pemerintah Daerah, Buku 1.

Rusmana Oman dkk, (2017). Akuntansi Pemerintah Daerah. Jakarta : Salemba Empat.

Rencana Strategis Kementrian Pendidikan dan Kebudayaan 2010 - 2014 GarisGaris besar program pembinaan SMK 2014.

Permendagri Nomor 64 Tahun 2013 tentang Penerapan Standar Akuntansi Pemerintah Berbasis Akrual Pada Pemerintah Daerah.

Peraturan Pemerintah Nomor 71, 2010 tentang Standar Akuntansi Pemerintah.

PP No 60 Tahun 2014 Tentang Realisasi pela poran dana desa.

Permendagri No 113 Tahun 2014 Tentang Laporan Keuangan Desa.

Peraturan Menteri Pendidikan dan Kebudayaan Republik Indonesia Nomor 70 tahun 2013 tentang kerangka dasar dan struktur kurikulum Sekolah Menengah dan Kejuruan/Madrasah Aliyah Kejuruan.

UU Nomor 20 tahun 2003 tentang Sistem Pen didikan Nasional.

Modul BPKP. (2013). Gambaran Umum 
Undang- Undang No 6 tahun 2014 Tentang Desa.

UU No 17 tahun 2003 mengenai Keuangan Ne gara.

UU No 1 tahun 2004 tentang Perbendaharaan Negara. 